\title{
Computation Model Study on Hot Blast System and Raceway of Blast Furnace
}

\author{
Jun-jun Zhu ${ }^{1}$,Yan Jin* ${ }^{2}$, Hui Yuan ${ }^{3}$,Xiao Luo ${ }^{3}$, Chen $\mathrm{Ye}^{3}$ and Fan $\mathrm{Ai}^{3}$ \\ ${ }^{1,2,3}$ Key Laboratory for Ferrous Metallurgy and Resources Utilization of Ministry of Education,Wuhan \\ University of Scienceand Technology,Wuhan 430081,Hubei, China
}

Keywords: Blast Furnace, Hot Blast System, Tuyere, Raceway, Simulation.

\begin{abstract}
Based on the actual production data from $3200 \mathrm{~m}^{3}$ (the effective furnace volume) blast furnace ; a model of blast furnace blast system was established with the software FLUENT. According to improve of blast furnace operation, the influence of the operation at the tuyere level to the distribution of blast volume between tuyeres was simulated, include changing the diameter of the tuyereor plugging some tuyeres; the formation of the raceway is simulated, and the effects of the blast volume, blast pressure, coke size and tuyeres diameter on the shape of the raceway are determined. The results indicate that when plug some tuyeres, the blast volume distribution between tuyeres become more inhomogeneous; when the diameter of some tuyeres are reduced from $130 \mathrm{~mm}$ to $120 \mathrm{~mm}$, the blast volume of those tuyeres reduce significantly; raceway depth in front of tuyere increased with the increased blast volume, blast temperature, tuyere diameter, tuyere insertion depth, and with the decreases coke size.
\end{abstract}

\section{Introduction}

In the blast furnace production process, the blast furnace is almost a "black box", so the operator is very concerned about the work condition of raceway of blast furnace [1,2]. The formation and reaction of raceway as well as reasonable hot blast distribution, that would directly affect the distribution of the lower part of blast furnace gas, the upper part of the blast furnace burden in equilibrium decline, and the entire blast furnace heat and mass transfer process $[3,4]$. Because of the high temperature and high pressure conditions, and gas, solid, liquid three-phase flow happened the complex coupled mechanical process and the chemical reaction process in the raceway[5,6],directly study is very difficult, so numerical simulation has great advantages [7].In this paper, the research on the blast furnace of $3200 \mathrm{~m} 3$, the FLUENT software is used to research on the hot blast distribution and the shape of the raceway, then to determine the influence of the hot blast supply system characteristics when changed the tuyere diameter and plugged the tuyere, and the influence of blast volume, blast pressure, blast temperature, the coke size, the tuyere diameter and the tuyere insertion depth on the shape of the raceway.

\section{Physical Description}

In this study of the model of hot blast system, is shown inFig1. The hot blast from the hot blast truck into the blast pipes, and divided into two symmetrical flows along the tube around circular motion then meet with in the half circular. In this process, the hot blast flow through the tuyere then stock into 32 tuyeres one by one; the hot blastpipes like a hot blast distributor, then the flow is divided into multiple small flows into the hearth, respectively. Numbering the tuyere in counterclockwise begin with the round hot blast pipes entrance. The model size and the important parameters, are given in Table 1.

\section{Mathematical Formulation and Assumptions}

In the flow field model of hot blast system, chosen the hot blast pipe center as the origin of coordinates, and establish the right Angle coordinate system. 
This study involved the tuyere raceway area as the computational domain. The distribution and movement rule of gas and coke in tuyere raceway are simulated by using Eulerian multiphase flow model in euler coordinate system

The governing equations for fluids flow used in the model are based on the equation of the continuity equation, the momentum equation, and the standard $\mathrm{k}-\varepsilon$ double equation[8.9].

Table 1.The blast furnace hot blast system parameters

\begin{tabular}{ll}
\hline Properties & Values \\
\hline The blast furnace volume $\left[\mathrm{m}^{3}\right]$ & 3200 \\
The hotblastpipediameter $[\mathrm{m}]$ & 2.1 \\
Tuyere diameter $[\mathrm{m}]$ & $0.12,0.13$ \\
Tuyere number & 32 \\
Blast volume $\left[\mathrm{m}^{3} \cdot \mathrm{min}^{-1}\right]$ & 6358 \\
Blast temperature $\left[{ }^{\circ} \mathrm{C}\right]$ & 1200 \\
Blast pressure $[\mathrm{MPa}]$ & 0.4 \\
\hline
\end{tabular}

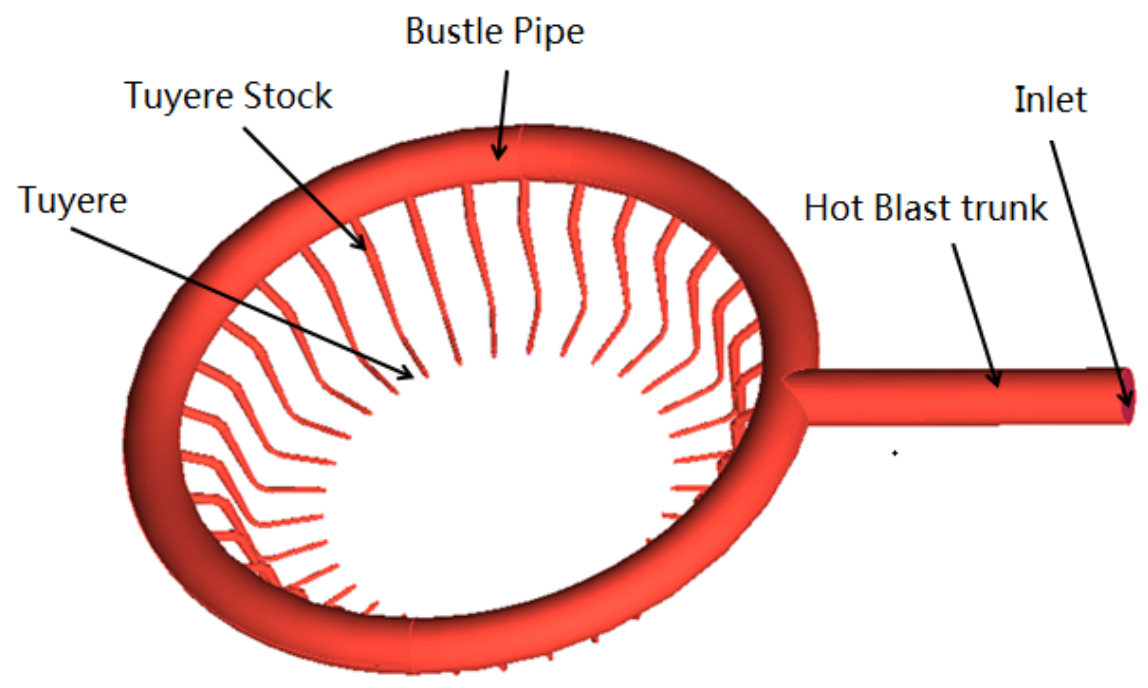

Fig1. The blast furnace hot blast system

\section{Assumption and Boundary Conditions}

\section{Assumption Made for This Study Included:}

(1) In the working conditions, the hot blast from hot blast trunk into the hot blast system, and the pressure at the top of the hearth is constant.

(2) In the process of flow the blast temperature is constant, at the same time, the hot blast is regarded as incompressible steady isothermal turbulent flow.

(3) The isothermal flow process in the raceway, but no combustion process.

\section{The Following Boundary Conditions Were Imposed:}

(4) Inlet boundary conditions: the hot blast flow as a condition of entry

(5) According to the hot blast total flow to determine the hot blast trunk entrance flow, the outlet pressure is the upper pressure of the hearth, $0.4 \mathrm{MPa}$. 
(6) No slip boundary condition is used in the wall surface of the pipe, and the standard wall function is adopted to calculate the flow near the wall.

(7) In the condition of $1200^{\circ} \mathrm{C}$ and $0.4 \mathrm{MPa}$ the gas density is obtained according to the ideal gas state equation.

\section{Results and Discussions}

\section{The Result Analysis of the Blast Volume Distribution}

\section{Effect of Plugging the Tuyere}
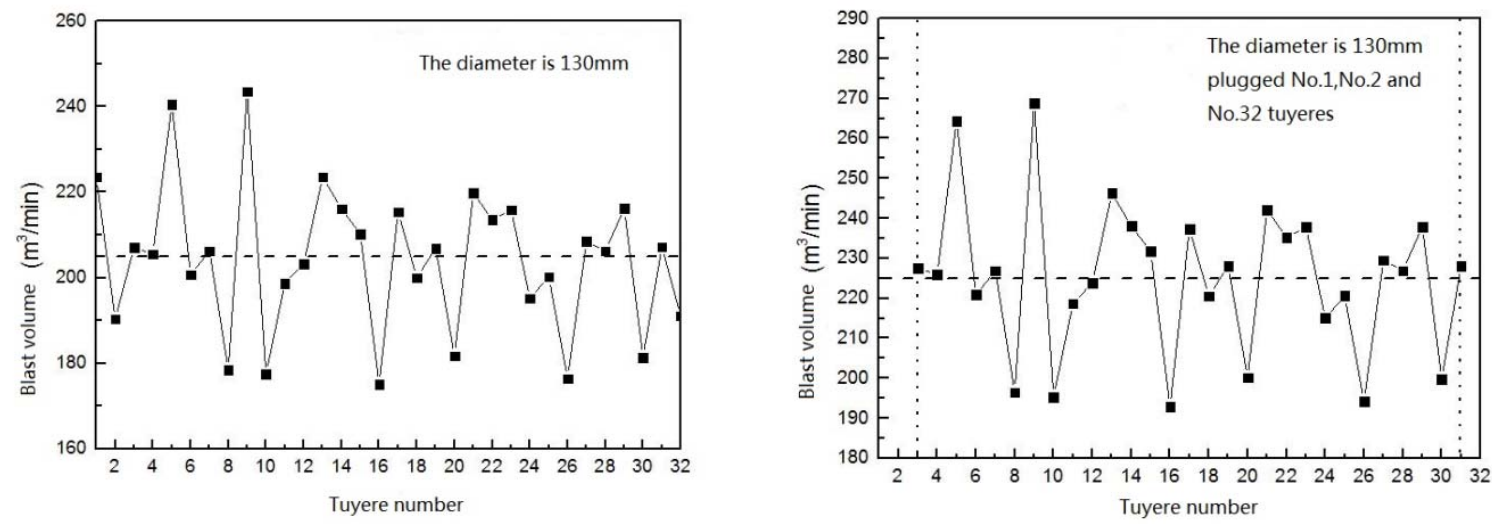

Figure 2.No pluggedFigure3.Plugged No. 1, 2 and 32 tuyeres

Figure2 shows when the tuyeres are not plugged, because of each tuyere is different from the distance of the hot blast trunk, and the hot-blast path in the bustle pipe is circular arc, so the blast volume distribution is not uniform in the tuyeres. Among them, the furthest distance is the No.16 tuyere and the hot blast trunk, and the blast volume of the tuyere is the lowest one, only $175 \mathrm{~m}^{3} / \mathrm{min}$; the minimum distance is the No.1 tuyere, the blast volume is just a little higher than average blast volume, $224 \mathrm{~m}^{3} / \mathrm{min}$; the blast volume of the No.9 tuyere is the highest one, up to $243 \mathrm{~m}^{3} / \mathrm{min}$.

Figure 3 shows when plug the No. 1, No. 2 and No. 32 tuyeres, those are the minimum distance from the hot blast trunk, have no effect on the symmetry of blast volume distribution and have the same blast volume distribution law as the tuyeres are not plugged. The furthest distance is the No.16 tuyere, the blast volume is the lowest one, only $193 \mathrm{~m} 3 / \mathrm{min}$; the blast volume of the No.9 tuyere is the highest one, up to $269 \mathrm{~m} 3 / \mathrm{min}$, and the symmetrical tuyere No.21 is also higher to $242 \mathrm{~m} 3 / \mathrm{min}$.
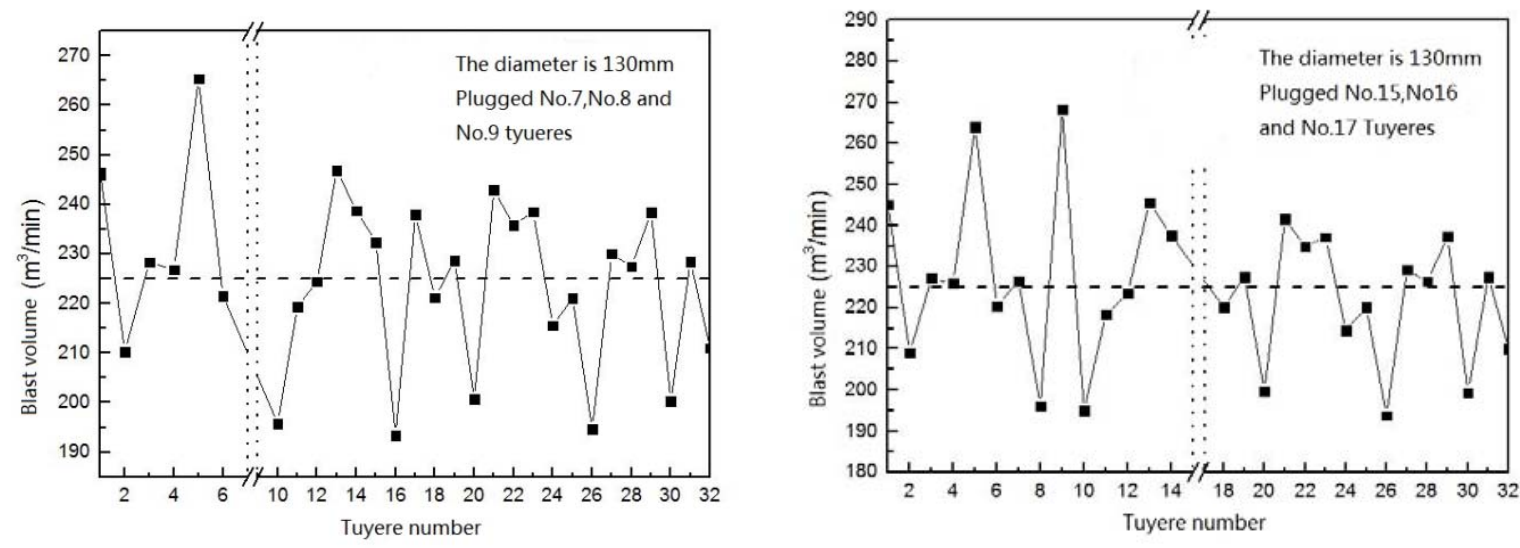

Figure4.Plugged No. 7,8 and 9tuyeresFigure5.Plugged No. 15, 16 and17tuyeres

Figure4showswhen plug the No. 7,No. 8 and No. 9 tuyeres, those are in the side of the hot blast 
trunk, have a great effect on the symmetry of blast volume distribution. The blast volume of the No.5 tuyere is the highest one, up to $265 \mathrm{~m} 3 / \mathrm{min}$; and the symmetrical tuyere No.21 is also higher to $243 \mathrm{~m} 3 / \mathrm{min}$.

Figure 5 shows when plug the No. 15, No. 16 and No. 17 tuyeres, those are opposite to the hot blast trunk, have no effect on the symmetry of blast volume distribution. Because of the No.10 and No.26 tuyeres are in the inner side of the corner of the bustle pipe, the blast volume of the tuyeres just only $194 \mathrm{~m} 3 / \mathrm{min}$; the blast volume of the No.9 tuyere is also the highest one, $268 \mathrm{~m} 3 / \mathrm{min}$; and the symmetrical tuyere No.21 is also higher to $242 \mathrm{~m} 3 / \mathrm{min}$.

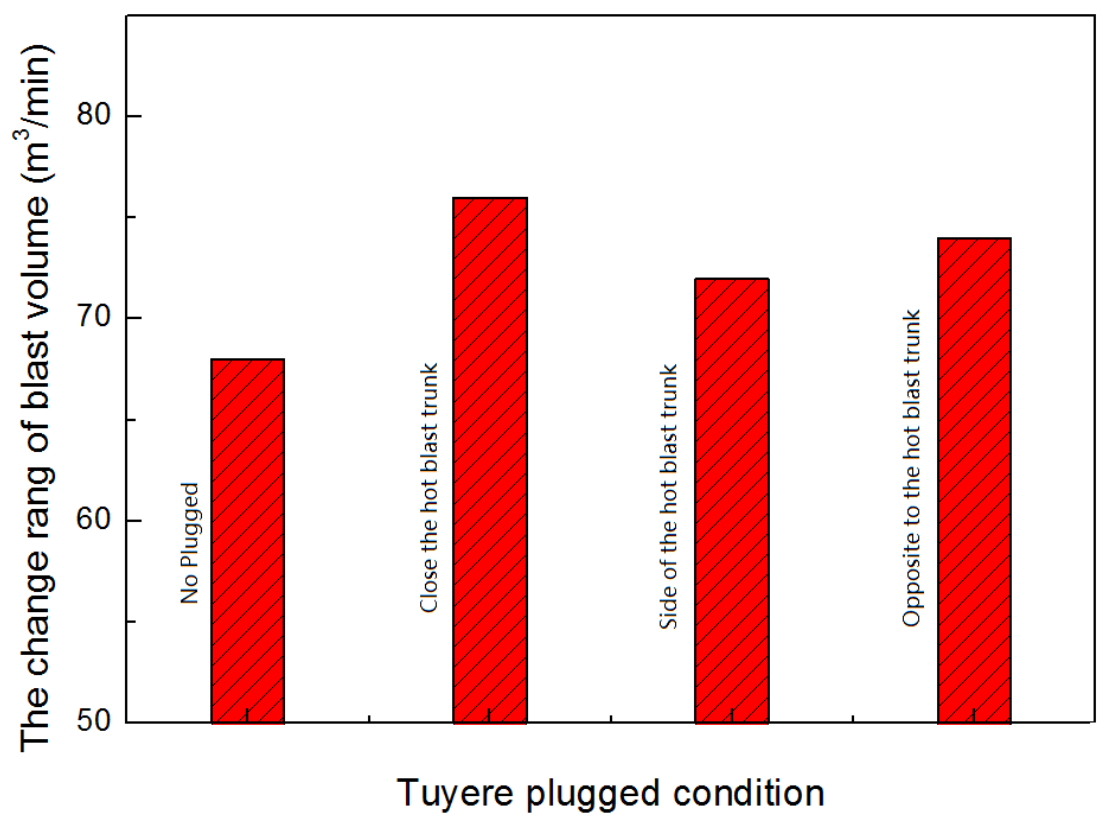

Figure 6 . The change rang of blast volume

The results showen in Figure 6, compare the difference in the highest and the lowest blast volume at different tuyere conditions (i.e. the change rang of blast volume).As shown in Figure 6, when the tuyeres are not plugged, the blast volume distribution is the most uniform; but when plug the tuyeres, the uneven distribution of the blast volume increases significantly; among them, plugging the three tuyeres closed to the hot blast trunk, the change rang of blast volume increase $12 \%$, reached $76 \mathrm{~m} 3 / \mathrm{min}$ compared with unplugged.

\section{The Influence of Tuyere Diameter on Blast Volume Distribution}

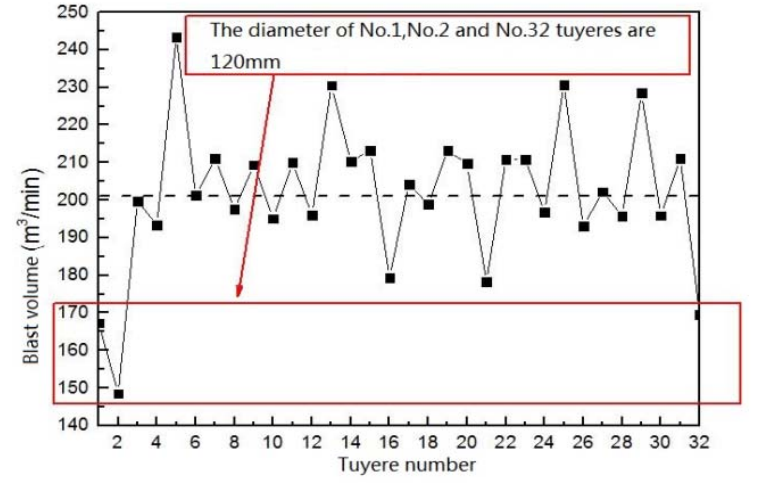

Figure7.The diameter of No. 1, 2 and 32 are $120 \mathrm{~mm}$

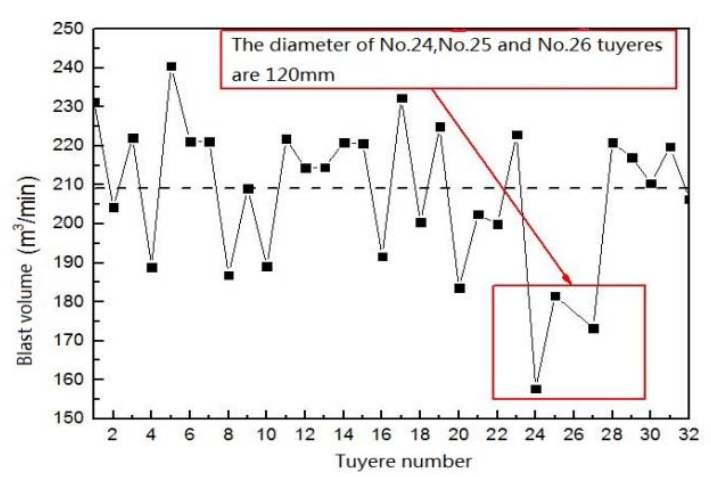

Figure8.The diameter of No.24,25 and 26 are $120 \mathrm{~mm}$ 


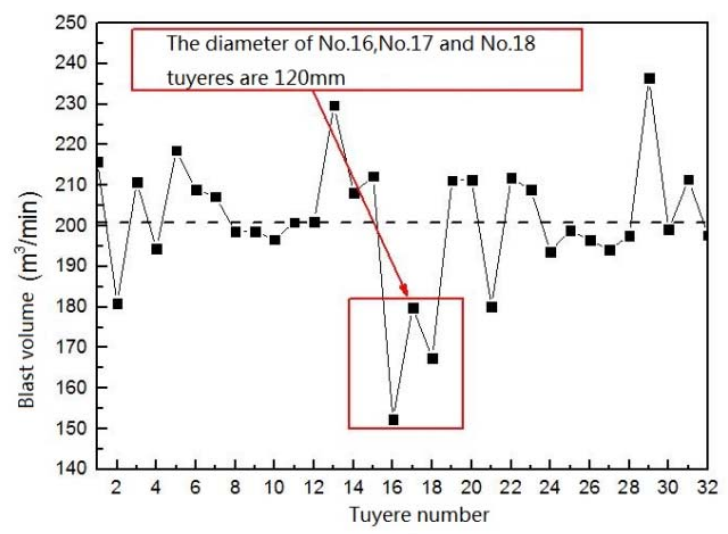

Figure9. The diameter of No.16, 17 and18 are $120 \mathrm{~mm}$

Figure7, 8 and 9 show when the diameter of the No.1,No.2 and No.32 tuyeres are $120 \mathrm{~mm}$, the diameter of the No.24,No.25 and No.26 tuyeres are $120 \mathrm{~mm}$, the diameter of the No.16,No.17 and No.18 tuyere are $120 \mathrm{~mm}$, respectively; and the others are $130 \mathrm{~mm}$. The blast volume of the tuyeres diameter reduce from $130 \mathrm{~mm}$ to $120 \mathrm{~mm}$ are lower than others. The result indicate that when change the diameter of the tuyeres, the blast volume of the smaller diameter of the tuyeres reduce significantly, and the others change less.

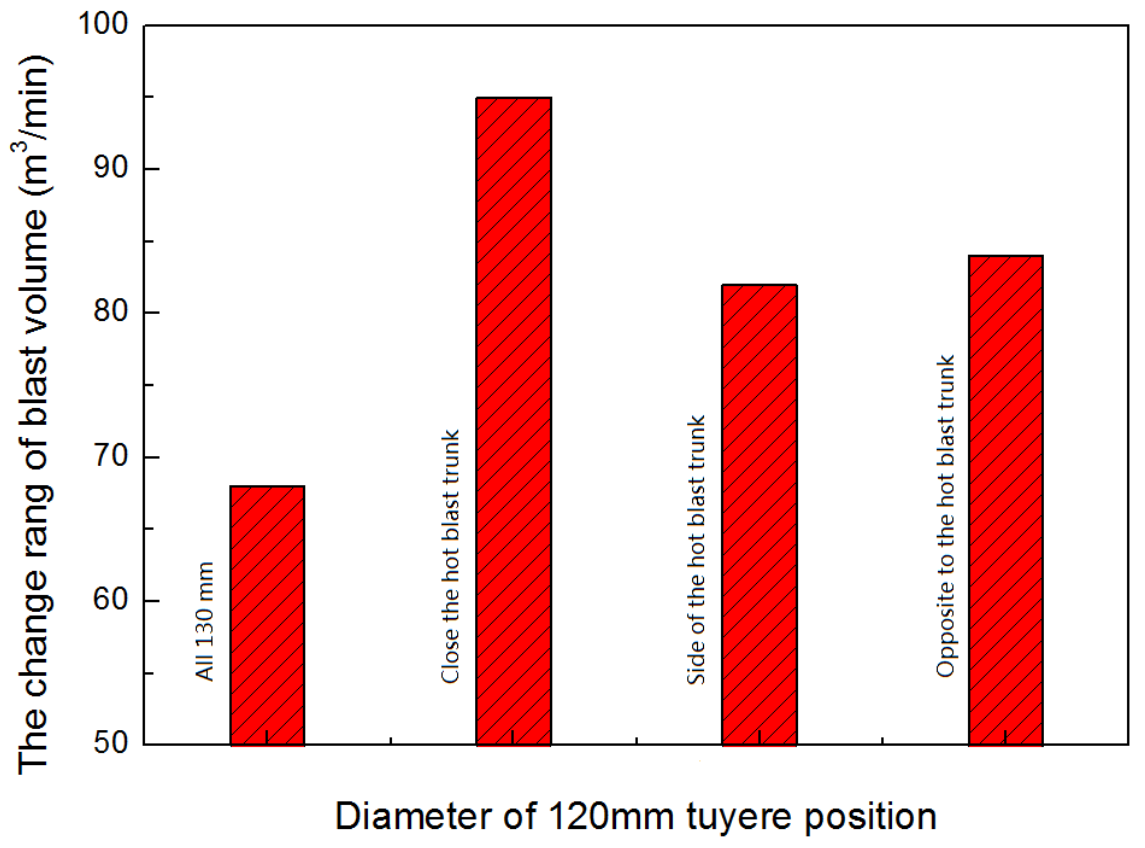

Figure10. The change rang of blast volume

The results showen in Figure10,change the diameter of the three tuyeres at different positions, compare the difference in the highest and the lowest blast volume (i.e. the change rang of blast volume).As shown in Figure 10, when change the diameter of the three tuyeres to $120 \mathrm{~mm}$, the uneven distribution of the blast volume increased significantly; among them, change the diameter of the three tuyeres are close to the hot blast main, the change rang of blast volume increase $40 \%$,reached $95 \mathrm{~m}^{3} / \mathrm{min}$ compare with unchange the diameter of the tuyeres. Therefore, it can be seen from the Figure 6 and Figure 10 that changed the diameter of the tuyeres or plugged the tuyeres, closed to the hot blast trunk, the influence on the uniformity of blast volume is much greater. 


\section{Analysis of the Shape of the Raceway}

\section{The Influence of Each Factor on the Depth of the Raceway}

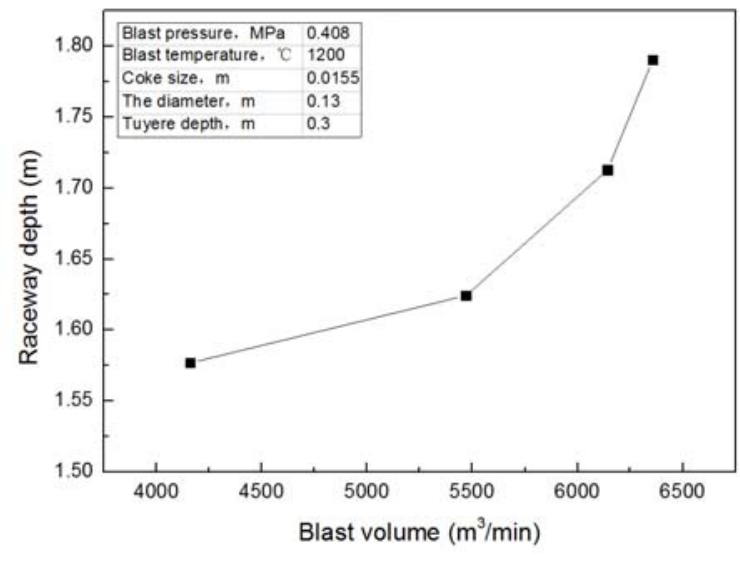

Figure11.Raceway depth and blast volume

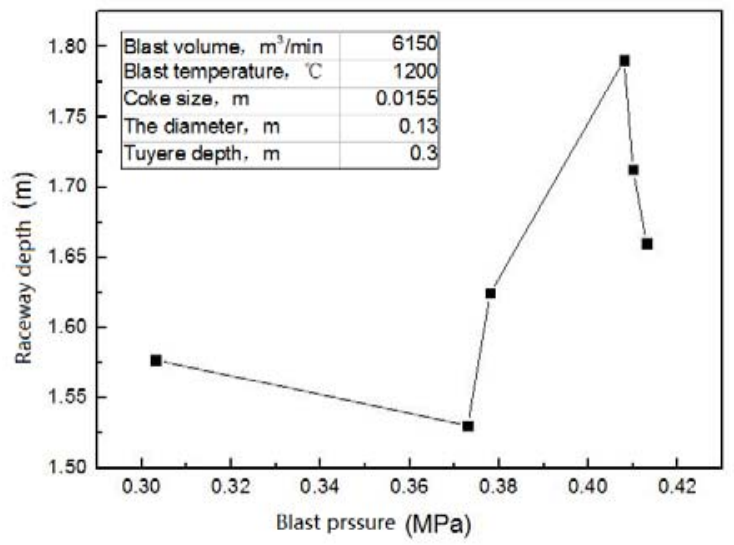

Figure12. Raceway depth and blast pressure

As shown in Figure 11, in the conditions of the blast pressure is $0.408 \mathrm{MPa}$, the blast temperature is $1200^{\circ} \mathrm{C}$, the coke size is $0.0155 \mathrm{~m}$, the tuyere diameter is $0.13 \mathrm{~m}$ and the tuyere depth is $0.3 \mathrm{~m}$, the depth of the raceway increases greatly with the blast volume increases. The blast volume in the range of 4000 to $5500 \mathrm{~m}^{3} / \mathrm{min}$, the depth of the raceway increases lightly, only from $1.58 \mathrm{~m}$ to $1.62 \mathrm{~m}$. However, when the blast volume more than $5500 \mathrm{~m}^{3} / \mathrm{min}$, the depth of the raceway increases sharply, from $1.62 \mathrm{~m}$ to $1.79 \mathrm{~m}$.

As shown in Figure 12, in the conditions of the blast volume is $6150 \mathrm{~m}^{3} / \mathrm{min}$, the blast temperature is $1200^{\circ} \mathrm{C}$, the coke size is $0.0155 \mathrm{~m}$, the tuyere diameter is $0.13 \mathrm{~m}$ and the tuyere depth is $0.3 \mathrm{~m}$. The blast pressure in the rang of $0.3 \mathrm{MPa}$ to $0.37 \mathrm{MPa}$, the depth of the raceway reduces slightly. The blast pressure in the rang of $0.37 \mathrm{MPa}$ to $0.4 \mathrm{MPa}$, the depth of the raceway increases sharply. But, when the blast pressure more than $0.4 \mathrm{MPa}$, the depth of the raceway reduces greatly; therefore, the blast pressure is $0.4 \mathrm{MPa}$, the depth of the raceway reaches the maximum.

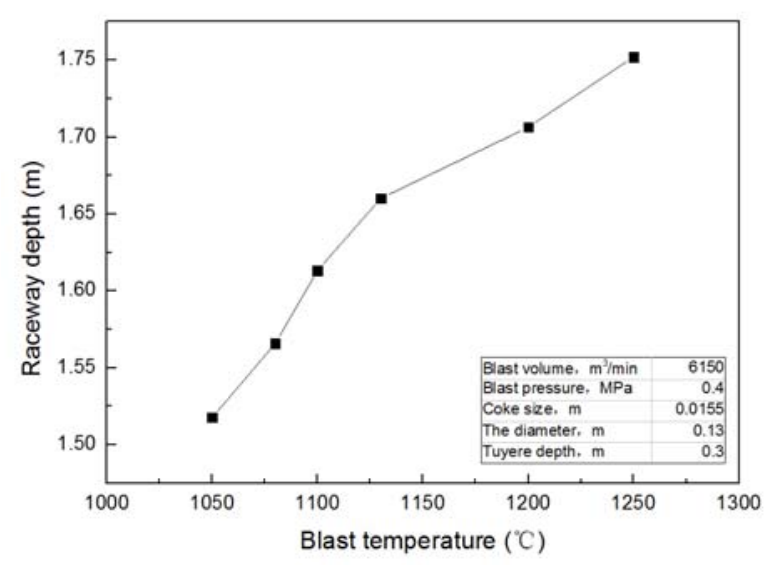

Figure13.Raceway depth and blast temperature

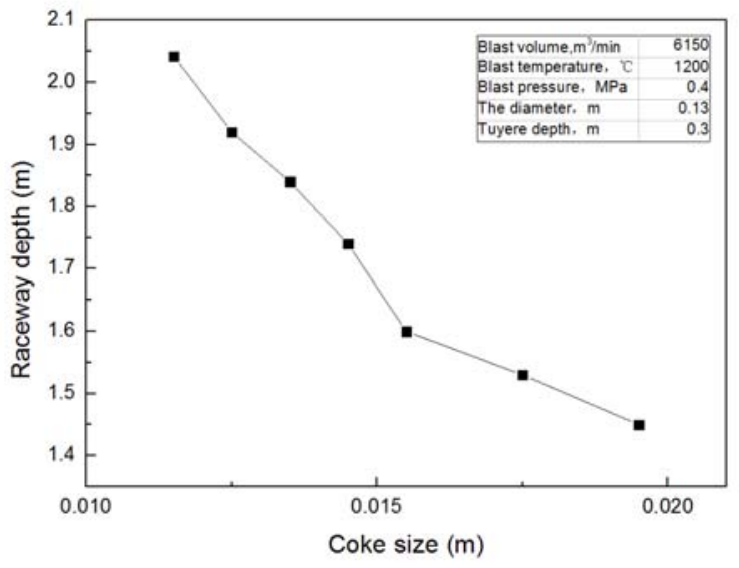

Figure14. Raceway depth and coke size

As shown in Figure 13, in the conditions of the blast volume is $6150 \mathrm{~m} 3 / \mathrm{min}$, the blast pressure is $0.4 \mathrm{MPa}$, the coke size is $0.0155 \mathrm{~m}$, the tuyere diameter is $0.13 \mathrm{~m}$ and the tuyere depth is $0.3 \mathrm{~m}$; the depth of the raceway increases with the blast temperature increases. The blast temperature in the range of 1020 to $1120^{\circ} \mathrm{C}$, the depth of the raceway increases greatly; the blast temperature in the range of 1120 to $1250^{\circ} \mathrm{C}$, the depth of the raceway increases slightly.

As shown in Figure 14, in the conditions of the blast volume is $6150 \mathrm{~m} 3 / \mathrm{min}$, the blast pressure is $0.4 \mathrm{MPa}$, the blast temperature is $1200^{\circ} \mathrm{C}$, the tuyere diameter is $0.13 \mathrm{~m}$ and the tuyere depth is 
$0.3 \mathrm{~m}$; the coke size is in the rang of $0.011 \mathrm{~m}$ to $0.0155 \mathrm{~m}$, the depth of the raceway reduces greatly with the coke size increases. The coke size more than $0.0155 \mathrm{~m}$, the depth of the raceway reduces slightly

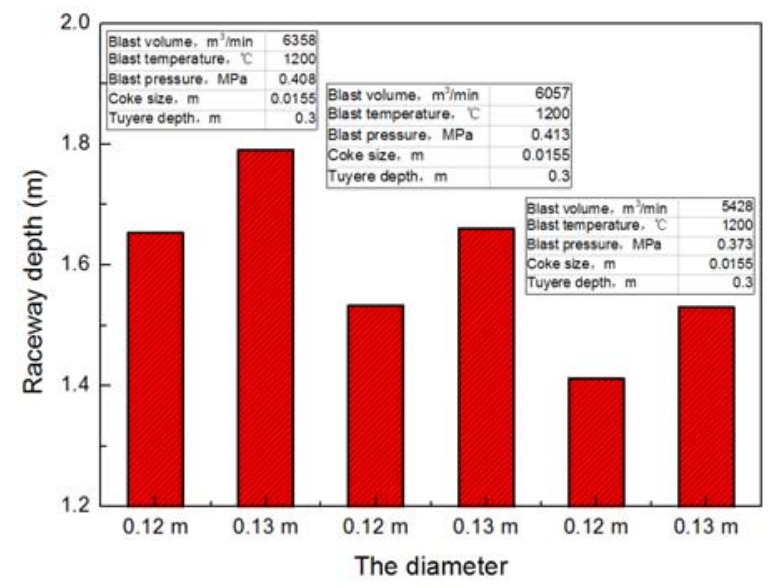

Figure16.Raceway depth and the diameter

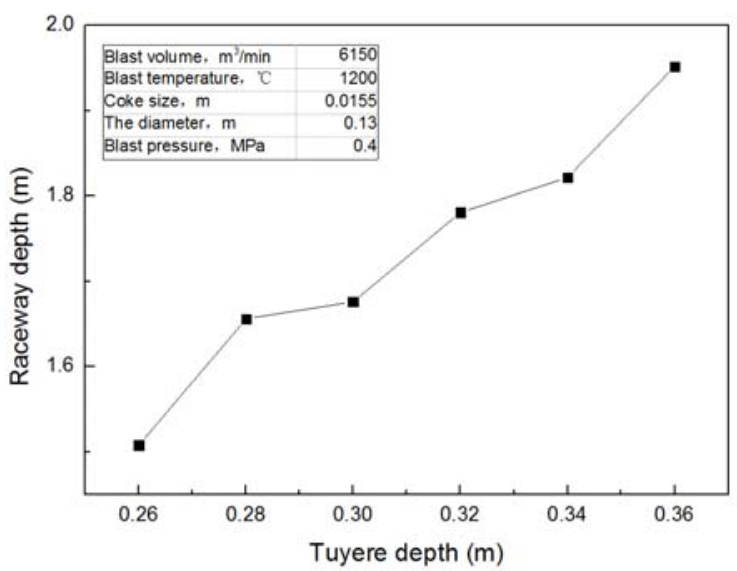

Figure17. Raceway depth and tuyere depth

As shown in Figure 15, under the normal operate conditions of the blast furnace, the depth of the raceway increases with the diameter of the tuyere; the tuyere diameter has a greater influence on the depth of raceway, while the blast pressure has little effect on the depth of the raceway, with the blast volume increases.

As shown in Figure 16, in the conditions of the blast volume is $6150 \mathrm{~m} 3 / \mathrm{min}$, the blast pressure is $0.4 \mathrm{MPa}$, the blast temperature is $1200^{\circ} \mathrm{C}$, the tuyere diameter is $0.13 \mathrm{~m}$ and the coke size is 0.0155 $\mathrm{m}$; the depth of the raceway increases linearly with the tuyere depth increases.

\section{Calculation Equation of the Depth of Raceway}

According to the discussion of the above factors, the simulation results are consistent with the empirical formula (1), which shows that this model is feasible to study on the raceway.

$$
\mathrm{D}_{\mathrm{R}}=0.41 \times\left[\frac{\rho_{0}}{\rho_{S} \times D_{P}}\left(\frac{V_{g}}{S_{T}}\right)^{2} \frac{T_{r}}{P_{b} \times 298}\right]^{0.69} \text {. }
$$

Where, DR is the depth of the raceway, $\mathrm{m}$; DP is the coke size, $\mathrm{m} ; \rho 0$ is the density of the gas, $\mathrm{kg} / \mathrm{m} 3 ; \rho \mathrm{S}$ is the density of the coke, $\mathrm{kg} / \mathrm{m} 3 ; \mathrm{Vg}$ is the gas volume flow rate, $\mathrm{m} 3 / \mathrm{s}$; ST is the total area of the tuyere, $\mathrm{m} 2$; $\mathrm{Tr}$ is the gas temperature in the raceway, ${ }^{\circ} \mathrm{C} ; \mathrm{Pb}$ is the blast pressure, $\mathrm{MPa}$.

\section{Conclusions}

(1)Plugging the tuyeres, the blast volume distribution become more inhomogeneous.

(1)The diameter of the tuyeres are reduced from $130 \mathrm{~mm}$ to $120 \mathrm{~mm}$, the blast volume reduced significantly.

(1)The raceway depth increases with the blast volume, the blast temperature, the tuyere diameter and the tuyere insertion depth increase, along with the increase of coke size reduces.

\section{References}

[1] Juan JI.Burden.Distribution Analysis by Digital Image Processing in a Scale Model of a Blast Furnace Shaft [J].ISIJ Int,2000,40(2): 114 120. 
[2] HenrikSaxen,MatsNikus JH. BurdenDistribution Estimation in the Blast Furnace from Stockrod and Probe Signals [J].Process metallurgy,2004,31(2):1 17.

[3] Zhanjun Long. Simulation Calculation and Experimental Study on Raceway of Blast Furnace. Master Thesis. ChongqingChongqingUniversity .2006,4.(in Chinese)

[4] Mathieson JG. Toward an Understanding of Coal Combustion in Blast Furnace Tuyere Injection[J].Fuel, 2005, 84(4):1229 1237.

[5] MorimasaI.Bebavior of Fines in the Blast Furnace[J].ISIJ Int,1992,32(4):505 513.

[6] Hiroshi TAKAHASHI MT.Burden Descending Behaviour with Renewal of Deadman in a Two Dimensional Cold Model of Blast Furnace[J].ISIJ Int,1996,36(11):1354 1359.

[7] Miaoxin Lin, Xiumei Wang, ShaoboZheng. 3D Numerical Simulation on Shape and Size of Blast Furnace Raceway. Shanghai Metals, 2013, 35(3).(in Chinese)

[8] Jun Fu. Computational Fluid Dynamics Analysis-CFD Software Theory and Application.Beijing: Tsinghua University Press, 2004.(in Chinese)

[9] YongbaoFan, Xiaoqiao Li, Lin Li.Simulation of Flow Field and Temperature Field of Blast Furnace Tuyere Based on FLUENT.Special Casting \& Nonferrous Alloys, 2009,29(4):324.(in Chinese) 